\title{
The Impact of Governance on State Owned Enterprises (SOEs) in Africa
}

\section{Emmanuel Innocents Edoun}

\author{
The University of Johannesburg, South Africa \\ edounsen@hotmail.com
}

Doi:10.5901/mjss.2015.v6n1p352

\begin{abstract}
The creation and strengthening of credible institutions is instrumental for any development initiative. Once these institutions are put in place, transparency and accountability become the tools for good governance to achieve socio-economic development. This article therefore set out to explore the impact that governance has on the developmental role of Public Enterprises in Africa. Public enterprises are created in Africa to contribute to socio-economic development. This study is therefore important in that, it thrives to explore why public enterprises have not over the years played the role for which they were created. However initial findings revealed that, the above failure is related to lack of leadership, maladministration and corruption which are the enemies of good governance, the State and of National Development Plan (NDP) as these impede any development initiative. This paper is divided into five major parts. The first part introduces the problematic of the research; the second part argues about the concept of governance, the third part discusses public enterprises reforms and the justification for decentralisation as a tool for the sustainability of public enterprises. The fourth part explains the methodological approach, data analysis and findings in using the Case of Cameroon. The Fifth part concludes and presents a set of recommendations for future research
\end{abstract}

Keywords: Governance, Decentralisation, State Owned Enterprises, accountability, transparency, Maladministration

\section{Introduction}

Since many African countries acceded to independence in the late $50 \mathrm{~s}$ and early $60 \mathrm{~s}$, African leaders have been struggling for years to put Africa in the path for economic development. The decisions agreed upon during the Monrovia Conference in 1979 that gave birth to the Lagos Plan of Action have not brought the expected socio-economic changes in African countries as many are still experiencing abject poverty and civil wars which are a direct result of lack of quality management, misleading policies and poor governance.

Also, the centralisation of powers in most African countries has contributed less for economic development. In this political set up, democratic governance institutions are completely absent and this had a negative impact in the functioning of state apparatus. The unstable socio-economic and political situations in Africa are therefore, the reasons why Africa has experienced problems in Lybia, Egypt, Cote d'Ivoire, the Democratic Republic of Congo (DRC), the Central African Republic (CAR) and in Nigeria with the intimidation of Boko Haram.

All of the above certainly have a negative impact in the management of public affairs including the management of state Owned Enterprises (SOEs) that are expected to engines in social transformation. The paper therefore argues that, in Africa, the absence of effective management of state affairs, governance and credible institutions is at the centre of the failure of SOEs to fulfill the mandate for which they were created. SOEs in Africa were created to stimulate economic development and contribute to the long term vision of modern democratic governments which is to contribute to economic growth, the reduction of unemployment rate and the eradication of extreme poverty. But with the Millennium Development Goal (MDG) expiring next year in 2015, Africa is still trapped in extreme poverty and this situation has made poorer countries like Liberia, Sierra Leone and Guinea Conakry to become vulnerable on challenges posed by the Ebola epidemic. The vulnerability of these countries is exposed because; SOEs created by the state in the health sector for instance are not functioning at full capacity to contain the virus. The heath sector is poorly managed because of lack of good governance. Poor governance is usually the reason why Africa is experiencing public unrest, Coup d'états and other related rebellions.

\section{The Concept of Governance}

The term governance is now frequently used as an interdisciplinary concept, that it is fast becoming a critical concept in the field development studies. In other words, any discussion on the subject of governance calls for an explanation 
depending on the context in which the word is used. Moreover, governance means different things to different people in different circumstances (Rhodes, 1996; Stoker, 1997). The various understandings of the term attempt to build a commonly accepted definition rather complex. Yet it is only a clear understanding of the context within which the word is used that anyone can constructively weigh in on any discussion of the same. Thus an exploration of the meaning of governance as used in this discussion is imperative.

If we may start off with a simple and broad definition, governance refers to the ordering of a group, community or society by a public authority with the overall objective of maintaining law and order, defending the said group, community or society against external attack and the advancement of 'the group's welfare' (Fox and Meyer,1996:55). In this regard, governance implies the creation of state institutions and structures of government to enable the former to effectively deliver services in line with the mandate entrusted to it by the people.

This definition is premised on the understanding that individual members of society cannot on their own effectively provide the quantity and quality of services that a government representing the people can provide collectively to the community' (Jonker, 2001). The group welfare referred to here would be analogous to 'the common good'. In his exposition on the common good (Dwivedi, 2002) argues that the concept means 'an action or a deed which is beneficial to all, although such benefits or privileges may not be immediately attainable or available, whether or not everyone realizes it....The concept means that everyone should receive or be given individual and collective due share'. Jonker, (2001) stipulates a number of core characteristics of a system of good governance. Among others, he highlights the need for openness and transparency, deliberation and consultation between the government and the governed etc.

On his part, Dwivedi (2002) understands governance to be a paradigm representing something more than government. He further considers it to mean a system of values, policies, and institutions by which a society manages its economic, political and social affairs through interaction within and among state, civil society and private sector.

Whereas Hyden and Braton, (1993:7) have postulated four basic elements that are key in understanding the term governance i.e. degree of trust, reciprocity of relationship between government and civil society, degree of accountability and nature of authority wielded; in addition to those four elements Dwivedi (2002) has argued that the scope of governance includes five main parts.

Firstly political governance which includes setting policies, resource mobilisation and ensuring that there are institutions and political systems that allow for popular participation. He then goes on to enumerate the other component parts of governance as being; economic governance; where economic and financial policy instruments are considered. The next element that he considers is the social governance, dealing specifically with values, norms, culture and acceptable standards of expected behavior. He points out another very intriguing part of governance which he refers to as 'green governance'. This portion deals with issues of the environment and sustainable development. The study found this rather interesting because it lends itself to the current green campaign that seems to have permeated all sectors of human life. The last portion should not come as a surprise to the spiritually aligned reader. He refers to this as the spiritual/Morality-inspired governance based on moral leadership. In conclusion he argues that governance implies a complexity of activities that are pluralistic and inclusive both by nature and in their decision making processes all taking place within a multiple institutional framework that empowers the weaker sections of society in its bid to achieve the generally accepted common good.

Mhone and Edigheji (2003) offer yet another twist to the concept of governance by referring to it as the manner in which the state apparatus is constituted, how it executes its mandate and its relationship to society, non-governmental organisations and community organisations and how it fulfills the substantive aspects of democracy. Their understanding of good governance is narrowed down to three aspects. That is, firstly, a rule-based, open, transparent, efficient and accountable government, secondly, for that type of government to execute its mandate in a participatory and consultative manner and thirdly the overall objective of the government should be to attain to the substantive aspects of democracy (sustainable human development). In summary, they see governance as both the overall environment that is deemed conducive to all three aspects of governance and the degree to which each of the three aspects are formalised and routinely made a part of the everyday affairs of the government and the state.

We shall consider a number of other approaches that have been advanced in trying to explain this complex term, but what is apparent is that every step in that direction seems to just lead to more complexity. Maybe it is because, the subject under consideration is indeed more complex than to be explained by one single theory or approach.

One key contributor to the governance debate has been the World Bank (WB) and its investment arm, the International Monetary Fund (IMF). In 1992, the World Bank defined governance as 'the exercise of political power to manage nation's affairs' (World Bank, 1992). The World Bank further considers good governance to be the embodiment of a transparent policy making process, informed by an enlightened professional bureaucracy, an accountable executive and a strong civil society participation in public affairs; all functioning under the ambit of the rule of law. 
It is important to assert that, the World Bank definition of governance well fits in this study because it takes into account a number of elements such as transparency, accountability and citizen participation which are very important within the broader framework of governance to advance the social justice discourse that is very critical in service delivery strategy. Social justice is likely to support service delivery in all sector of the economy if there is transparency and accountability as depicted in the model for effective governance below which is the cornerstone of quality management in any sector of the economy.

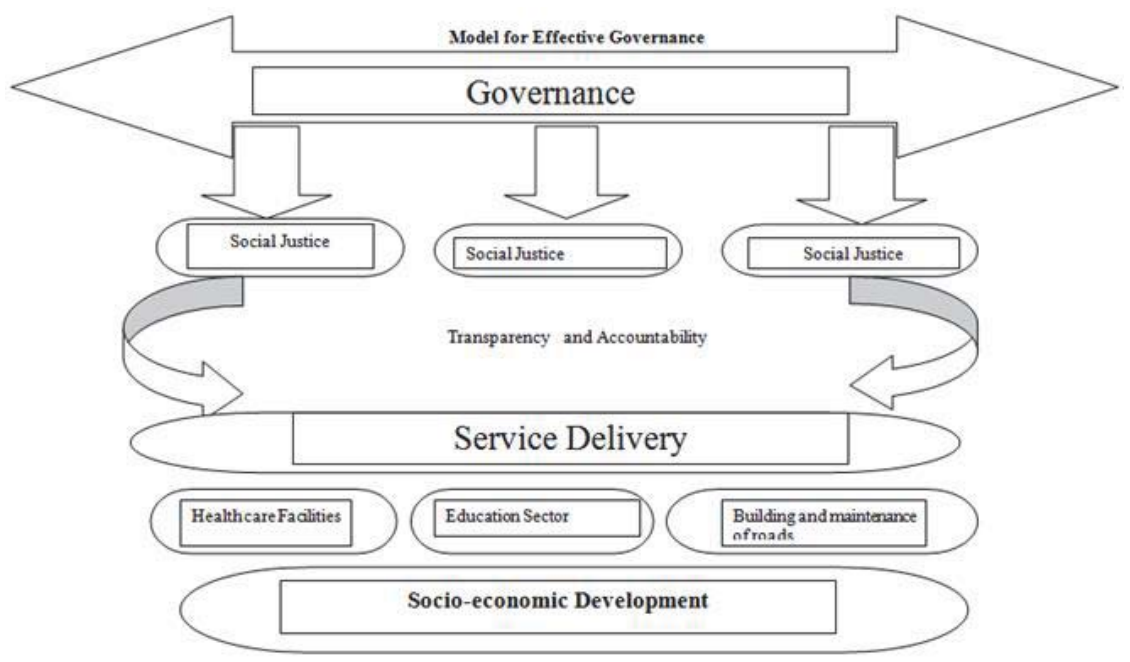

It is therefore imperative that, any democratic government in Africa engage into public enterprise reform if it aspires to achieve developmental results through SOEs. Public enterprises in Africa are not functioning at full capacity because politicians frequently used them for political interest which according to the current study is a form of maladministration that impedes the achievement of development objectives set in the National Development Plans. Reforms can either be exogenous or endogenous depending on the policies that are suitable for such reforms.

\section{Public Enterprises Reforms and the Justification for Decentralisation as a Tool for Good Governance in this Study}

Reforms are usually adopted as a result of failed policies and strategies that were unable to meet goals set by government departments. This failure is usually attributed to the lack of quality management, transparency and accountability which are the fundamental principles of governance. The strengthening of democratic governance institutions is a key factor for any development initiative. With these institutions in place, accountability becomes a yardstick to achieve greater results. However, past studies have revealed that, public enterprises failed to contribute to economic and social development. The reason for this failure is strongly related to politicians who used SOEs for political interest. Public Enterprises are the channel by which political leaders redistribute wealth by giving employment to comrades who lack the necessary skills and knowledge to manage SOEs. Taking into consideration the role that these SOEs play in supporting the agenda of political leaders and maintaining them in power, it is difficult for them to support the full transformation of SOEs.

As a result, this type of political behavior strongly compromises the role that public enterprises are set to play in stimulating social and economic development. A strict implementation on SOEs reform ought to eliminate jobs for comrades and current subsidies. This action, the study found could cost the support base of the government in power. The World Bank (WB) wrote a report in 1995 related to the "Economics and Politics of Government Ownership". The WB (1995) report revealed that, politicians who rely on SOEs support usually resist any change in SOEs policy that is not in their advantage. The report argued that, while some exceptional leaders may be able to change their support base and mobilise new constituents in favor of reform, most are inherently responsive to the supporters who put them in office (IBRD, 1995).

From the above arguments, one could easily see that, as many politicians are wresting to stay in power, they are likely to resist any reform that is not supporting their political agenda. With this type of behavior unfolding, it is the interest of the majority that is at stake because their participation in the process of decision-making is blocked as a result of 
mismanagement and bad governance. These scenarios are easily found in poor countries, mostly in Africa where Head of State are reluctant to relinquish power. In trying to find solutions related to political obstacles on SOEs reform, the WB (1995) revealed that three conditions should be taken into consideration for successful reform, these must be related to political desirability, feasibility and credibility. Once these conditions are effectively considered, the reforms become efficient and SOEs could start playing its development role effectively. This means that community leaders could now be represented in decision making processes that concern the well being of the community that they lead. But reinventing public enterprises necessitates robust and progressive strategies that are capable of drastically changing the role of public enterprises in Africa

As Rondinelli (2005) put it, reinventing public enterprises in any country should begin with a comprehensive performance review and the formulation of a government strategy for reform. Rondinelli (2005) strongly argued that, governments are unlikely to be successful in restructuring public enterprises unless they develop a strategy that sets out a clear vision for how state-owned enterprises are expected to contribute to development and defines clear missions and performance criteria for each public enterprise.

Rondinelli (2005) convincingly argued that, the vision for reform of the South African public enterprises at the macro-economic level was to attract foreign direct investment (FDI), contribute to the reduction in public borrowing and assist the development of an economy that promotes industrial competitiveness and growth and increased domestic savings. He further posits that, the South African government set social imperatives on public sector reform that included the need to increase employment and rationalise or develop new skills in the labour force as well as promote wider ownership and participation in the South African economy. Different approaches were also used in other countries that did not overlooked the developmental role of SOEs, but all depends on how serious are the governments in these countries in implementing reforms that are free of maladministration and corruption.

In countries such as Cameroon, privatisation was embraced in 1986 as part of the reform process as a result of economic crisis that was persistent in 1985-1986. In Africa and elsewhere in the world, the International Monetary Fund (IMF) and the World Bank consider privatisation as a critical element of their policy for economic liberalisation and structural adjustment. But reasons should be well define on why countries need to privatise rather than mobilising funds locally to revive failed SOES

Elliot et Al (1996) argued that the Relief of budget burdens is one of the two most common reasons why governments adopt privatisation programs; the other is increased efficiency. In the same vein, a study by Nzongang and Nzomo (2007) revealed that, the poor performance of SOEs in Cameroon was a result of maladministration and corruption which forced the government to sign agreements with the International Monetary Fund (IMF) and the World Bank in order to rehabilitate SOEs in Cameroon. By introducing rehabilitation on SOEs, Cameroon was bound to corroborate with a number of measures that were imposed by the Breton Woods Institutions which were not welcomed by the general public. Some of these measures included the liquidation of SOEs, the decrease in salary as well as early retirement. The privatisation process of SOEs in Cameroon was part of the restructuring process that requires a sound implementation strategy if it is to use privatisation as a tool for economic renewal. However, the different reforms models put in place required a clear vision and a development oriented type of strategy to better address the problem at hand which are related to poor performance of SOEs, embezzlement of state funds, corruption, maladministration, favouritism, nepotism and lack of ethics.

A broader assessment of this privatisation process in Cameroon revealed that, the process was not welcomed by the majority of population even though the initial objective was to stimulate economic growth, reduce state costs and attract Foreign Direct Investment (FDI). More than $80 \%$ of the population mostly the youth felt that, the privatisation of SOEs contributed a lot in rising unemployment rate, because it came with its own set of measures that were misleading . The opponents of privatisation argued that, the Structural Adjustment Programme (SAP) did not provide the government enough room to generate a conducive environment for job creation, specifically for young graduates. Rather, most Cameroonians are accusing the government for appointing party supporters who in turn are involved in the embezzlement of SOEs funds.

Many of such comrades are languishing in Jail in notorious prisons in KODENGUI, SED or NEW BELL. Many of these civil servants have abused their positions by using state funds for personal interest. These funds embezzled are deposited in foreign banks in Europe and elsewhere in the world. These greedy civil servants failed Cameroon and the youth who are without dissent employment. The country lack of infrastructure is the result of irresponsible civil servants who did not used the funds for the purpose for which they were allocated. As a result a number of SOEs were trapped in bankruptcy and became a financial burden for the State.

However, the current research is of the view that apart from privatisation, public sector reforms require strong democratic governance institutions to support strategies such privatisation. Decentralisation in the process has been 
identified as a tool to strengthen transparency and accountability. Decentralisation being an instrument of good governance, the article has attempted to explore if its applicability on (SOEs) could stimulate economic development. A policy of decentralisation could be considered as an important tool for economic development if the process is adequately implemented. A number of definitions are related to the concept of decentralisation that is instrumental in support of good governance initiative in the context of development.

The study has identified three types of decentralisation models that support governance in their respective contexts. The first model of decentralisation is related to de-concentration where power is transferred but not resources. This model of decentralisation is the one that is responsible of the failure of most SOEs in Africa. For political reasons, the State appoints an individual to run a SOEs without given him the necessary resources to manage the company. In this scenario, the government appoints what is termed "government delegates" who manage the resources and communicate directly with the central government. The danger in this form of decentralisation is that, the appointed civil servant is unaware of other political decisions that might land him into trouble as the government delegate is running the show

Another form of decentralisation is the delegation of powers. Dyer and Rose (2005) inferred that, this form of decentralisation involves leaving a degree of decision making to the lower level but the delegated system still rests on the central authority where the power can be withdrawn. Dyer and Rose (2005:) describe de-concentration and delegation of authority, as involving the shifting of management responsibilities from the center to the lower level, but the center retaining the overall control of powers.

The third form of decentralisation is the devolution of power where there a total transfer of power and resources from the upper to the lower level of government. This form of decentralisation might be very important for the autonomy of SOEs which reflects good corporate governance. However, when SOEs are facing problems, government for reform sake, usually choose the delegation of power to address rising problems with the intention of turning around economic performance.

For the purpose of this study, decentralisation is considered as a corrective instrument that seeks the use of accountability and transparency as a quality management method for better results. The justification of the raison d'être of decentralisation in stimulating sustainable economic development through SOEs is relevant to the current study.Decentralisation being a credible tool for good governance, it applicability to SOEs surely intends to minimise corruption and government interference.

For decentralisation purpose, privatization was thus identified as a strategy meant to discharge government from its role in managing SOEs. As part of the decentralisation process, privatization is viewed as a strategy conceptualized to add some impetus in competitive markets forces. It aims at replacing the state by eliminating its role while encouraging the involvement of the private sector focusing on management and service delivery. These strategies were mainly imposed by the Bretton Woods Institutions such the International Monetary Fund (IMF) and the World Bank (WB).

Decentralisation policy through privatization is expected to identify the best option that is result-oriented, the best bidder should be equipped with the necessary expertise to lead the privatization process. As Van Niekerk et al (2001) put it, performance -based or outcomes-oriented contracting should be the ultimate objective of efficient and effective governance in the privatization process. Privatization is a robust strategy that requires the necessary know how to lead its process successfully. Many countries have struggle to implement this process and the results have not being encouraging.

Even though privatization has generated positive results in turning around the economic situation in some countries, in others the same has not happened. The study argues that, this failure of privatization in stimulating economic growth might be related to the fact that, the primary objective of the involvement of the private sector is to maximize profit rather than putting the interest of people first. The above could be the reason why, many experts have mixed feeling on the developmental role expected from privatization. In most cases, the process do not involved current employees during the decision-making process; they are totally excluded from the process and this reflects bad on the issue of governance and its implication on SOEs .

\section{Methodology, Analysis of Related Information and Key Findings}

The study used the case of Cameroon and has selected seven SOEs that were included in the Structural Adjustment Programme (SAP) imposed by International Monetary Fund (IMF) and the World Bank (WB). These SOEs were privatised and the researcher managed to interview employees who lost their jobs as a result of the privatisation imposed by the structural adjustment measures that were implemented by Cameroon in 1990 and 1994. The study is qualitative in nature and relied on document analysis, information from the internet and countries economic reports. In-depth interviews 
and questionnaire assisted in collecting relevant information from the respondents. This information was important in such a way that, the researcher was able to understand the problems that led to the privatisation of SOEs in countries such as Cameroon and consequently to the lost of employment as a result of structural adjustment measures.

The following table displays selected privatized SOEs in Cameroon. This table also included selected individuals that were laid off as a result of the privatization process

List of selected SOEs that were privatised and selected number of individuals that were laid off

\begin{tabular}{|c|l|c|c|c|}
\hline & & Male & Female & Total \\
\hline $\mathbf{1}$ & Regifercam & 4 & 2 & 6 \\
\hline $\mathbf{2}$ & SOCAPALM & 8 & 5 & 13 \\
\hline $\mathbf{3}$ & SODECOTON & 4 & 5 & 9 \\
\hline $\mathbf{4}$ & CAMAIR & 7 & 4 & 11 \\
\hline $\mathbf{5}$ & CAMSUCO & 7 & 5 & 12 \\
\hline $\mathbf{6}$ & SNEC & 9 & 4 & 13 \\
\hline $\mathbf{7}$ & SONEL & 8 & 3 & 11 \\
\hline & & $\mathbf{4 7}$ & $\mathbf{2 8}$ & $\mathbf{7 5}$ \\
\hline
\end{tabular}

The African development Bank conducted a study on "Project Performance Evaluation Report" in November 2002. In this report, it was clearly explained that, a number of SOEs were privatized under the structural adjustment program, thirty in total. Some of these included: REGIFERCAM, SOCAPALM, SODECOTON, CAMAIR, CAMSUCO, SNEC, SONEL, among others. The report posits that, the reform process was very complex and Cameroon did not have the necessary expertise to finalize this privatization process ( AfDB, 2002).

Selected individuals as per the table above strongly argued that, the privatization process was not transparent enough internally. $97 \%$ of these individuals argued that, employees were not involved and did not get the necessary information related to the privatization process. $98 \%$ convincingly agreed that, the internal governance related to the privatization process was not transparent enough. They argued that, decisions were executed at the center and accountability was non- existent, this type of management approaches is the reason why SOEs failed to perform at full capacity as the central government failed to share important information with those who were the victim of the structural adjustment program strategies. Many lost their employment and were unable to meet the basic needs of their immediate families. This situation plunged a numbers of former employees of privatized SOEs in abject poverty as a result of structural adjustment measures that forced many to lose their employment.

In summary therefore, the Afdb Report (2002) strongly argued that, the programme for the privatization/restructuring of public enterprises was ambitious, beside the fact that, a number of projected strategies were not implemented. The report further inferred that, the Cameroon civil service did not have the required experience to deal with the complexity of the paper work.

\section{Conclusions}

Governance is an important concept in development initiative. The concept of governance in the field of development studies has generated numerous debates around it effectiveness in managerial decision making. Experiences have shown that, the failure of African governments to achieve sustainable economic development was partly due because of maladministration, corruption and bad governance. The failure of SOEs to achieve the developmental role for which they were created is the reason why, many African countries decided to seek help from the Bretton woods Institutions in the early 1990s .In choosing the case of Cameroon, this article was able to assess the role that the Structural Adjustment Program played in conducting reform as a result of the economic crisis and corruption in that country. The reform was able to decentralize 0through the privatization of a number of public enterprises which were expected to revive the economy and create much needed growth and employment. However, the study found that, the privatization of major SOEs in Cameroon was not welcome by all because the process did not involved current employees in decisions-making process. It is also found that, the profit maximization factor linked to privatization created mixed reaction from local experts who felt that, the profit maximization component played a negative role in that, it did not encouraged the private sector to put the interest of the people at heart.

The article therefore recommends that, during the SOEs reform process, it is imperative that, the process of decentralisation be taken into consideration through the privatization process which according to Van Niekerk et $A l$ is a comprehensive economic, social and political strategy that is designed to increase competitive markets forces. This 
definition convincingly advocates for the reduction of government power that is expected to be replaced by the private sector. The policy of privatization should be designed in such a way that it takes into account, the interest of the people first. It should be designed with clear objectives that should be result-oriented

\section{References}

African Development Bank AfDB (2002): Cameroon Structural Adjustment Programme ii (sap ii) Project Performance Evaluation Report (pper) Operations Evaluation Department (OPEV) 14 November 2002

Dewald van Niekerk, Gerrit van der Walt, and Alan Jonker, 2001. Governance, Politics, and Policy in South Africa. Cape Town: Oxford University Press

Dwivedi, O.P. 2002. On Common Good and Good Governance:An Alternative Approach. In D. Olowu and S.Sako, (eds) Better Governance and Public Policy, 2002. pp 35-51. Bloomfield,CT-USA:Kumarian Press,Inc

Fox,W.and Meyer,I.H.1995.Public administration dictionary.Kenwyn:Juta.

Hyden, G. and M. Bratton, (eds) 1993. Governance and Politics in Africa. Boulder, Colo., Lynne Rienner Publishers.

Mhone, G. and Edigheji,O., 2003. Globalisation and the Challenges of Governance in the New South Africa. In M.Guy and E.Omano, (eds) Governance in the New South Africa.The Challenges of Globalisation, 2003. pp 1-15. University of Cape Town Press and University of the Witwatersrand. Cape Town South Africa.

Rhodes, R. 1996. The New Governance:Governing without Government, Political Studies, 44, pp 652-67.

Stoker, G.1997. Regime Theory and Urban Politics. In D. Judge et al, Theories $f$ urban Politics

State of the Nation Address by the President of South Africa, ,Nelson Mandela. Houses of Parliament, Cape Town, 24 May 1994http://www.anc.org.za/ancdocs/history/mandela/1994/sp940524.html

World Bank, 1992. The World Development Report. Washington DC:World Bank. 